\title{
Implementation of Technology Based SAK EMKM
}

\author{
Neny Tri Indrianasari, Emmy Ermawati \\ Department of Accounting, STIE Widya Gama Lumajang \\ Email: indriana85@gmail.com
}

\section{A R T I C L E I N F O}

Received:

2 January 2021

Revised:

2 March 2021

Accepted:

7 March 2021

\section{A B S T R A C T}

This study aims to analyze the application of Information Technology-based Accounting based on SAK EMKM. MSMEs face various obstacles or problems caused by 1) low education 2) a lack of understanding of information technology, and 3) obstacles in preparing financial reports. The Lamikro application system complies with the Accounting Standards for Micro, Small, and Medium Enterprises (SAK EMKM). The presence of the Lamikro application according to the EMKM SAK is expected to help MSME players in Indonesia in preparing financial reports because the Lamikro application can make it easier for MSMEs to make financial reports whose transactions are cash in nature. Business development using accounting financial statement applications is very necessary, the goal is that users, in this case, MSME players throughout Indonesia, can monitor the financial activities of MSMEs. This type of research used in this research is descriptive research with qualitative. approach. This research concludes that the financial records of Joys Kitchen and Rezky Photocopy still use traditional or manual recording so that they do not know the recording of financial statements in accordance with EMKM's Financial Accounting Standards and are still constrained in inputting financial report transactions using Lamikro.

Keywords: Professionalism, Fraud, EMKM

Cite this as: Indrianasari, N. T., Ermawati, E. (2020). Implementation of Technology Based SAK EMKM. Wiga : Jurnal Penelitian Ilmu Ekonomi, 11(1), 1-11. https://doi.org/10.30741/wiga.v11i1.650

\section{INTRODUCTION}

Industrial revolution 4.0 is an integration of the use of the internet with production lines in the industrial world. Changes have also occurred in today's industrialized world which is marked by changes in the business climate and an increasingly competitive industry due to developments in information technology, sometimes even current developments are no longer linear with what has happened in the last decade. In industrial revolution 4.0, the size of the company is not a 
guarantee, but rather in the direction of how the company's agility in accommodating or anticipating changes that occur.

The impact of major changes in industry 4.0 has been researched and studied by the Mckinsey Global Institute with the conclusion: Industry 4.0 will have a broad impact in the industrial world because of the use of robotics and machines which have a wide impact on the labor sector in particular. However, on the other hand, positive benefits will be obtained in the industrial revolution process because the process of digitization and robotics will increase work efficiency and effectiveness.

In this context, MSMEs and cooperatives as business actors must be prepared and anticipate these developments. Data from the Central Statistics Agency (BPS) in 2017, the total number of MSMEs in Indonesia is almost 60 million MSMEs. Of this number, $98.74 \%$ were microbusinesses, then around $1.15 \%$ were small business actors and $0.10 \%$ were medium enterprises. One thing that distinguishes this type of business is in terms of turnover. It is said that large businesses have an annual turnover of more than IDR 50 billion with assets of more than IDR 10 billion. Medium-sized businesses are businesses with an annual turnover of IDR 2.5 billion to IDR 50 billion with assets of IDR 500 million to IDR 10 billion. Small businesses are there businesses with a turnover of between Rp. 300 million to Rp. 2.5 billion with assets of Rp. 50 million to Rp. 500 million. From this data, micro-businesses have the largest number. However, there are still a lot of human resources from these micro-business actors that need to be improved. Many of these business actors have not paid attention to financial bookkeeping issues.

MSMEs face various obstacles or problems caused by 1) low education 2) lack of understanding of information technology, and 3) constraints in preparing financial reports(Muchid, 2015). The more a business develops, such as increasing business funding, it is necessary to deal with parties outside the company, either the bank or other financial institutions. The bank / financial institution will usually require financial reports to see the feasibility of providing credit. With the growing business, it requires MSMEs to provide financial reports in accordance with applicable standards.

Related to these conditions, Bond Indonesian Accountants (IAI) publish Financial Accounting Standards for EMKM, namely, SAK EMKM (Micro Entity Financial Accounting Standards Small and Medium) which apply effectively for drafting financial reports starting January 1, 2018. SAK EMKM is an accounting standard much simpler if compared to SAK ETAP. Indonesian Accountants Association (IAI) states that Law No. 20 of 2008 concerning Business, Micro, Small, and Medium (UMKM) can be used as a reference in define and provide vulnerable qualitative MSMEs that must apply SAK EMKM.

Along with the development of information technology has a significant impact on the accounting recording process in a company. The real impact that can be felt is that data processing has changed from manual systems to computer systems. Various accounting software has been developed by several experts to assist company operations (Karte 2017). Even today, accounting software is not only used on computers but can also be used on smartphones. The use of smartphones is easy and can be used in all situations and places, making smartphones one of the devices chosen by current company owners to carry out company operational activities such as recording and accounting (Jessica 2018).

Currently, smartphones are widely used by all groups, including business people. One of the smartphones that are widely used by the public is the Android-based smartphone. Besides being easy to use, its smart Android-based phones have an affordable price. Many features have been developed by Android-based application developers to make it easier for users, such as financial and social media features. This feature can be used by business actors to facilitate company operations in terms of managing finances and promotions. 
Government involvement has taken part in encouraging micro, small and medium enterprises (MSMEs) to be able to present proper business bookkeeping in the midst of the industrial revolution 4.0 era. The Ministry of Cooperatives and SMEs has launched an application related to financial bookkeeping for micro-entrepreneurs (Lamikro) which can only be accessed by microscale entrepreneurs. Lamikro is considered to be able to make it easier for business actors to have financial reports independently. By only downloading, business actors can record transactions via cell phones (cell phones), then the application will automatically calculate their own losses and profits. This application can be a business performance tool, it can be viewed periodically.

This Lamikro application system is in accordance with the Financial Accounting Standards for Micro, Small, and Medium Entities (SAK EMKM). The presence of the Lamikro application according to the SAK EMKM is expected to help MSME players in Indonesia in preparing financial reports so that it is made easier when applying for access to funding from various financial institutions. Until now, MSME users of the Lamikro application have reached 3,259 users. This number will continue to grow along with the socialization and training that is carried out. The Chairperson of the Indonesian Accountants Association (IAI) assessed that the Lamikro application was a solution for MSMEs, which so far had conventional financial reporting because the Lamikro application could provide convenience for MSMEs in making financial reporting for cash transactions.

Joys Kitchen and Rezky Fotocopy are businesses engaged in food services and photocopies are included in the micro category because they have a net worth of less than IDR 25,000,000, this is in accordance with the criteria for MSMEs based on Law Number 20 of 2008 concerning Micro, Small and Medium Enterprises (UMKM). This business does not yet have well-administered financial management. First, this company still keeps simple accounting records, not all sales transactions are made by sales notes so that evidence of transactions is not properly archived. Second, financial management at Joys Kitchen and Rezky Fotocopy has not separated business needs and personal (household) needs. Third, the company does not have an accounting system of books and records in accordance with applicable standards. so that the owner of the company cannot know the amount of profit or profit that is actually generated. It is included in the micro business category and to respond to problems experienced, Joys Kitchen and Rezky Fotocopy must prepare financial reports in accordance with SAK EMKM.

Industry 4.0 is marked by increasing digitization of manufacturing driven by four factors: 1) increasing data volume, computing power, and connectivity; 2) the emergence of business analysis, skills, and intelligence; 3) the occurrence of new forms of interaction between humans and machines; and 4) improvement digital transfer instructions to the physical world, such as robotics and 3D printing. Lifter and Tschiener (2013) added that the basic principle of industry 4.0 is the combination of machines, workflows, and systems, by implementing an intelligent network along the chain and production processes to control each other independently. (Yahya, 2018)

According to (Warsita, 2011)Information technology are the means and infrastructure (hardware, software, useware) of systems and methods for obtaining, transmitting, processing, interpreting, storing, organizing, and using data meaningfully. The same thing is also expressed by Lantip and Rianto (2011: 4) that information technology is defined as knowledge in the field of computerbased information and its development is very rapid. Hamzah B. Uno and Nina Lamatenggo (2011: 57) also argue that information technology is a technology used to process data.

Romney in Rahmawati et al (2010) stated that the use of information technology in the organization is not a basic strategy of the organization, the implementation of information technology is used to assist in achieving the organizational strategy. By utilizing information technology, access to the company's business processes can be done quickly so that decisionmaking can be done more quickly and accurately and in the end, organizational goals can be achieved. 
According to Suwardjono (2008), accounting standards are concepts, principles, methods, techniques, and others that are deliberately selected on the basis of a conceptual framework by a standard drafting body (or authorized) to be enforced in an environment or country and set forth in an official document in order to achieve the purpose of the country's financial reporting. SAK itself is needed in order to create uniformity in the preparation of financial reports. Not only that, but SAK also regulates two things in the preparation of financial reports, namely measurement standards and disclosure standards. The measurement standard in question is the regulation on the measurement of each transaction that occurs. The disclosure standard itself regulates what and how an event, transaction, Lutfiaazahra, 2015).

In 2009, the Financial Accounting Standards Board of the Indonesian Institute of Accountants (DSAK IAI) issued the Financial Accounting Standards for Entities without Public Accountability (SAK ETAP) to be applied to small and medium-sized entities. However, seeing the need for simpler accounting standards for micro, small and medium enterprises, DSAK IAI issued the Financial Accounting Standards for Micro, Small, and Medium Enterprises (SAK EMKM). SAK EMKM contains a simpler accounting arrangement than SAK ETAP because it regulates transactions conducted by EMKM with a pure measurement using historical costs. SAK EMKM is expected to be able to assist MSME players in preparing financial reports so that it will make it easier for MSME players to get access to funding(Indonesian Accounting Association, 2016). The basis for measuring the elements of financial statements in SAK EMKM is historical cost. The historical cost of an asset is the amount of cash or cash equivalents paid to acquire the asset when it was acquired. The historical cost of a liability is the amount of cash or cash equivalents received or the amount of cash expected to be paid to meet the liability in the ordinary course of business. Fair presentation of financial statements requires entities to present information that is relevant, representative, comparable, and understandable. An entity shall provide a complete financial statement at the end of each reporting period.

\section{METHOD}

This type of research uses a descriptive approach qualitative This research uses an approach with descriptive qualitative methods, in which qualitative research is research that intends to understand the phenomena experienced by research subjects, for example, behavior, perceptions, motivation, etc. holistically and by means of descriptions in the form of words and Language, in a specific context which is natural and by making use of various scientific methods. Data collection techniques used in this research are interviews, observations, literature study, and documentation.

In qualitative research, data analysis has been carried out before entering the field, during the field, and after completing research. In this study, researchers used a qualitative descriptive data analysis method. Where, in this study discusses problems that are in nature using, describing, and comparing a data or situation and then explaining a situation in such away. The data analysis process in this study: 1) Collecting data related to the accounting standards implemented by MSME actors which can be seen from the resulting financial reports. 2) Reviewing the readiness of MSME actors in implementing SAK EMKM through interviews with MSME owners. 3) Separating the main data and supporting data obtained from interviews and collecting related data in the form of literature and documentation. 4) Comparing financial reports prepared by MSMEs with financial reports based on Financial Accounting Standards for Micro, Small, and Medium Entities (SAK EMKM). 5) Determine the results of research based on the data that has been obtained, draw conclusions, and provide advice related to the implementation of SAK EMKM and educational institutions that overshadow current researchers.

\section{RESULTS AND DISCUSSION}


Joys Kitchen was founded in 2020 which is engaged in food. MSME financial transaction processing is still done manually. Likewise, every transaction is handwritten on paper, resulting in an untidy, too complex file that allows data loss. This is done is recording in a journal, moving to a ledger to produce information in the form of financial reports. Likewise, Rezky Fotocopy was founded in 2020, which is engaged in the service sector. Researchers implemented a financial data processing application using an application from the Ministry of Cooperatives and SMEs through the Deputy for Human Resources developing an application called LAMIKRO (Micro Business Accounting Report). This application is simple, easier to learn, and suitable for various types of businesses in Indonesia. By implementing financial transactions using LAMIKRO, it is hoped that it can improve the quality of information, accuracy of the information, and efficiency of information in the company

At the first time observing at Joys Kitchen, the researcher asked whether Joys Kitchen had compiled Financial Statements in accordance with SAK EMKM, here the owner of Joys Kitchen, Mrs. Bagusl, said that her business had not compiled financial reports according to SAK EMKM because she did not have enough accounting knowledge so he only keeps simple bookkeeping which includes income and expenses.

The researcher also confirmed that the owner of Joys Kitchen has an android smartphone that is always connected to the internet considering that the LAMIKRO application can only be operated with an internet connection. From the interview results, the owner does use an Android smartphone and also regularly buys monthly internet packages because he is active on social media such as Facebook, WhatsApp, Youtube, and so on.

After knowing that Joys Kitchen has not compiled financial reports according to SAK EMKM and has supporting facilities, namely an android smartphone that is always connected to the internet, the researcher introduced and explained the LAMIKRO application to the Joys Kitchen owner where this application can be used via an android smartphone which aims to facilitate owners in preparing financial reports in accordance with SAK EMKM. After hearing the explanation that using the LAMIKRO application can help owners compile financial reports that are in accordance with SAK EMKM, the owner's response to the existence of this application is very positive and feels very interested in learning more about the LAMIKRO application.

The Profit and Loss Statement explains that the net profit after tax obtained during the month of June is Rp. 6,904,305, - while on bookkeeping Joys KitchenIt is not known the benefits obtained because the bookkeeping used is still limited to revenues and expenses, this is very different from the profits generated from the preparation of an income statement using the LAMIKRO application which is in accordance with SAK EMKM. The resulting profitability ratioJoys Kitchen namely through the calculation of the Net Profit of Rp. 6,939,000 divided by the total income of Rp. $6,939,000$ multiplied by $100 \%$, obtaining $100 \%$ results, this illustrates the company's ability to earn profits through sales activities.

The Statement of Financial Position is a report that reflects the actual condition of the business so that the owner can make the right financial decisions. The Financial Position ReportJoys Kitchen June 2020 by using the LAMIKRO application, it can be seen that the total assets owned are Rp 11,129,000 which consists of Current Assets Rp 8,719,000 and Fixed Assets Rp 2,410,000, Total Liabilities of Rp. 0, consisting of short-term liabilities of Rp. 0 and long-term liabilities of Rp. 0. Capital of Rp 4,000,000. Joys Kitchen does not have liabilities short-term and long-term liabilities so that the business activities are quite good. 


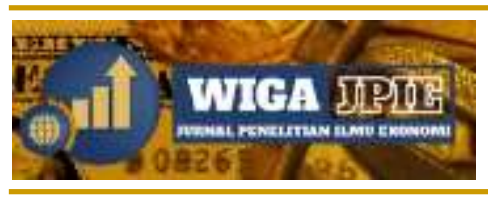

Q9umb i

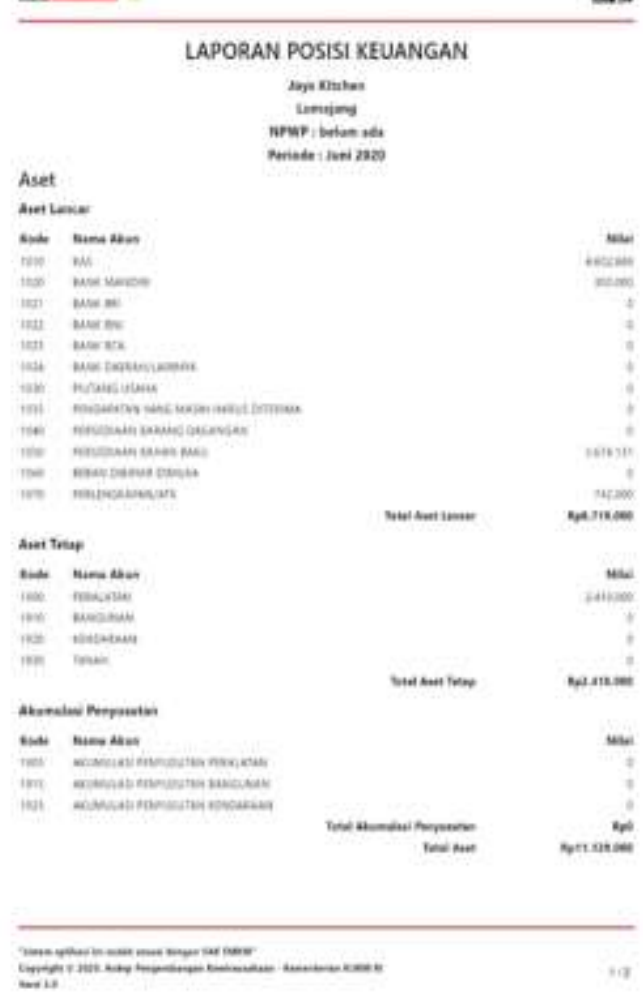

E-ISSN : 2549-5992, P-ISSN : 2088-0944

Available online at:

http://ejournal.stiewidyagamalumajang.ac.id/index.php/wiga

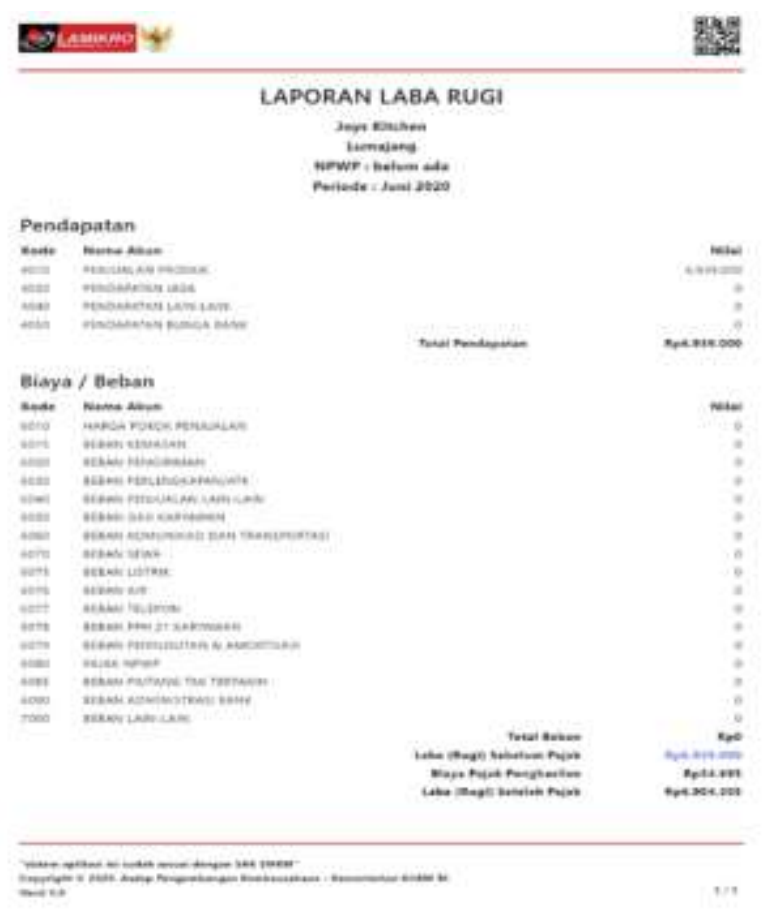

Picture 1. Financial Statements UMKM 1 
At the first time observing at the Rezky Photocopy Shop, the researcher asked whether the Rezky Photocopy Shop had compiled a Financial Report in accordance with SAK EMKM, here the owner of the Rezky Photocopy Shop, Mr. Khoirul said that his business had not compiled a financial report according to SAK EMKM because he did not have enough knowledge of accounting so that he only keeps simple bookkeeping which includes revenues and expenses.

The researcher also confirmed that the owner of the Rezky Fotocopy Shop has an android smartphone that is always connected to the internet considering that the LAMIKRO application can only be operated with an internet connection. From the results of the interview, the owner does use an android smartphone and also regularly buys monthly internet packages because he is active on social media such as Facebook, WhatsApp, Youtube, and so on.

After knowing that the Rezky Fotocopy Store has not prepared financial reports according to EMKM SAK and has supporting facilities, namely an android smartphone that is always connected to the internet, the researcher introduced and explained the LAMIKRO application to the owner of the Rezky Fotocopy Store where this application can be used via an android smartphone which aims to make it easier for owners to prepare financial reports in accordance with SAK EMKM. After hearing the explanation that using the LAMIKRO application can help owners compile financial reports that are in accordance with SAK EMKM, the owner's response to the existence of this application is very positive and feels very interested in learning more about the LAMIKRO application.

The Income Statement explains that the net profit earned during the month of June is Rp. $5,058,453$, - whereas, in the bookkeeping of the Rezky Photocopy Store, it is not known the benefits obtained because the bookkeeping used is still limited to revenues and expenses, this is very different from the profit generated from the preparation of an income statement using the LAMIKRO application which is in accordance with SAK EMKM. The profitability ratio generated by the Rezky Photocopy Store is through the calculation of the Net Profit of Rp. 5,090,000 divided by the total income of Rp. 6,690,000 multiplied by $100 \%$, obtaining $76 \%$ results, this illustrates the company's ability to earn profits through sales activities.

The Statement of Financial Position is a report that reflects the actual condition of the business so that the owner can make the right financial decisions. The Fotocopy Rezky Store Financial Position Report of June 2020 by using the LAMIKRO application, it can be seen that the total assets owned are Rp.32,090,000 which consists of Current Assets Rp 7,940,000 and Fixed Assets Rp 24,150,000, Total Liabilities of Rp. 0, consisting of short-term liabilities of Rp. 0 and longterm liabilities of Rp. 0. Capital of Rp 32,090,000. Toko Rezky Fotocopy has no liabilities for both short-term and long-term liabilities so that its business activities are quite good. 


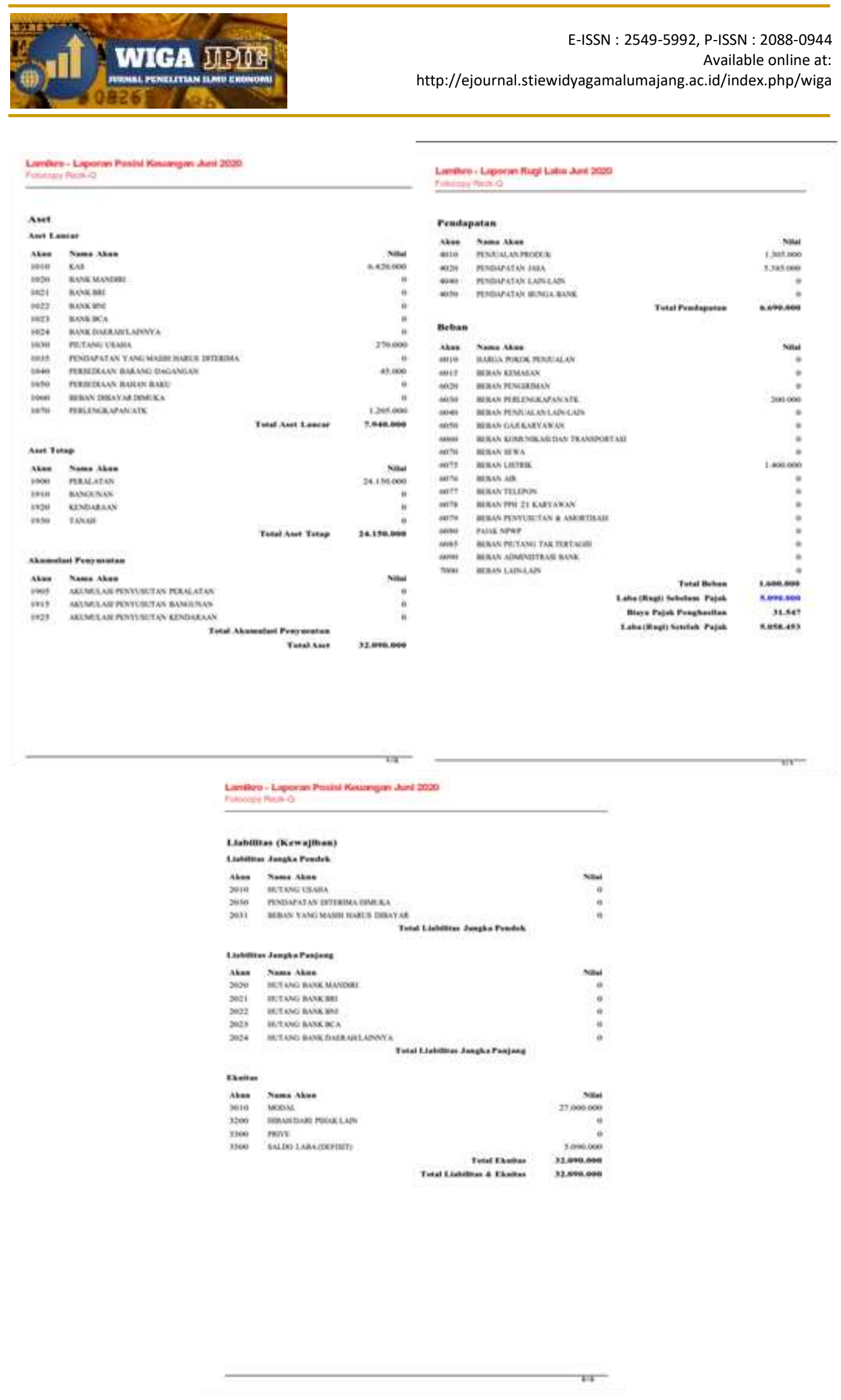

Picture 1. Financial Statements UMKM 2 
Based on the research results, it shows that with the LAMIKRO application, different results are obtained from manual accounting records. In the era of the industrial revolution 4.0 to develop its business, EMKM needs to use the accounting financial statement application. This can be seen clearly the difference between the computerized accounting system and the manual system according to table 4.1 .

Table 4.1 Differences between computerized accounting systems and manual systems Computerized Systems Manual System

1. Automatically, the computer will 1. Transfer journals into accounts in the general overbook transactions in groups ledger.

(batch) or when they occur (online)

2. Enter and post the adjusting entry. 2. Enter the remaining balance into the worksheet, Print financial reports. After backing up the accounting data for this period, perform the closing procedures automatically. The initial residual value for the next period will automatically appear as a result of the closing. and complete the worksheet. Compile financial reports, do journalism and book-entry of adjusting entries, do journalism and book-entry closing entries. Arrange the adjusted balance sheet. This balance sheet will be the basis for phase 1 for the next period

As for the obstacles experienced by Joys Kitchen and the Rezky Photocopy Store in compiling financial reports according to SAK EMKM using the LAMIKRO application, this was conveyed by Mrs. Bagus as the owner of Joys Kitchen on July 3, 2020, and Mr. Khoirul as the owner of Rezky Photocopy at 07 July 2020 at 10.00 WIB: "The difficulties I experienced were like when I was going to enter a daily journal, at first I had difficulty choosing what accounts to use maybe because I didn't have much knowledge about accounting but this has been resolved thanks to guidance from relatives and also indeed the application has been made in language. which is easy for ordinary people to understand like me, besides that the account cannot be made as needed so you have to adjust the same as what is already in the application, difficulties are also experienced when editing wrong journal entries because you have to delete and create a new one. "

Thus it can be concluded that the obstacles experienced by Joys Kitchen and Toko Rezky Photocopy according to the results of the interview, namely: The owners of Joys Kitchen and Toko Rezky Fotocopy do not have sufficient accounting knowledge, so at the beginning of the daily journal entry period they had a little difficulty choosing which account to use at the time of journal entry, but this can be handled properly because the LAMIKRO application uses words which are easily understood by users such as the type of transaction, the type of transaction can be filled using a droplist containing options such as income, expenses, accounts payable, payable, accounts receivable, accounts receivable, additional capital, capital withdrawals, asset transfer, and adjustments. If the user selects the transaction type of income, a journal entry window will appear containing received from the droplist, namely grants / from other parties, product sales, other income, and interest income, then the owner only needs to choose the product sale. After that there is a Save To, this section also contains a droplist that can be easily selected by the user, namely: Cash, Bank, merchandise inventory, raw material inventory, prepaid expenses, equipment/stationery. A journal entry window that uses easy-to-understand language, can help users determine which accounts are related to the transactions that have occurred.

The LAMIKRO application already provides accounts for users, but they cannot be edited or created a new account according to user needs. Journals that have been entered cannot be reedited, so when an error occurs the user must first delete the previous journal and then create a new journal to correct the wrong journal. The use of the LAMIKRO application must use an internet connection so that if the user does not have an internet connection, this application cannot 
be used. It is difficult to download financial reports in pdf form via a smartphone, so it has to go through the web version www.lamikro.com.

\section{CONCLUSION}

Based on the results of hypothesis testing and referring to the formulation and objectives of this study, the following conclusions can be drawn the results of the study found that financial records Joy's Kitchen and Rezky Fotocopy still use traditional or manual recording so they don't know the recording of financial statements that are in accordance with EMKM's Financial Accounting Standards and are still constrained in inputting financial statement transactions using Lamikro. In the era of the Industrial Revolution 4.0 Developing a business using an accounting financial statement application is highly required, therefore it is necessary to conduct socialization and training on the implementation of SAK EMKM using the Lamikro application and assistance from the government. This implies that the owners of MSMEs are expected to have the awareness to implement them and start the preparation of more systematic financial reports. It is feared that the cash-based recording method that has been carried out by the majority of MSMEs may give a false picture of long-term profitability. Therefore, implementing SAK EMKM today is no longer an option, but a prerequisite for the company's success.

Limitations in this study include the low awareness of informants in doing bookkeeping due to a weak understanding of and the importance of bookkeeping for their business. This resulted in the interview in data collection was not optimal. Another limitation is that informants do not fully cover most of the large MSMEs in Lumajang Regency. In addition, the need for bookkeeping in a form that is in accordance with SAK EMKM is still very low because informants use a simple bookkeeping system.

\section{REFERENCE}

Azizah R, D. A., Hariyadi, M., \& Andrianto, A. (2019). Analisis Penyusunan Laporan Keuangan Umkm Batik Jumput Dahlia Berdasarkan SAK-EMKM. BALANCE: Economic, Business, Management and Accounting Journal. https://doi.org/10.30651/blc.v16i1.2453

Herawati, N. T. (2017). Penyusunan Laporan Keuangan Sesuai Dengan Standar Akuntansi Keuangan Entitas Mikro, Kecil, Dan Menengah Pada Usaha Ternak Ayam Boiler. EJournal Universitas Pendidikan Ganesha Jurusan.

IAI. (2009). Standar Akuntansi Entitas Tanpa Akuntabilitas Publik. Standar Akuntansi Keuangan

Ikatan Akuntansi Indonesia, I. (2016). Standar Akuntansi Keuangan Entitas Mikro, Kecil, dan Menengah. Sak Emkm.

Istiana, D., \& Ariyati, I. (2017). Sistem Informasi Akuntansi Perusahaan Dagang Menggunakan Zahir Accounting Versi 5.1. Information Management for Educators and Professionals.

Kirowati, D. (2019). Implementasi Standar Akuntansi Keuangan Entitas Mikro, Kecil dan Menengah (SAK EMKM) pada Laporan Keuangan di Era Revolusi Industri 4.0 (Studi Kasus Pada UMKM di Kota Madiun). Jurnal AKSI (Akuntansi Dan Sistem Informasi). https://doi.org/10.32486/aksi.v4i1.316

Lutfiaazahra, A. (2015). Implementasi Standar Akuntansi Keuangan Entitas Tanpa Akuntabilitas Publik (SAK ETAP) Pada UMKM Pengrajin Batik di Kampoeng Batik Laweyan Surakarta. In Prosiding Seminar Nasional Pendidikan Ekonomi \& Bisnis Fakultas Keguruan dan Ilmu Pendidikan Universitas Sebelas Maret Surakarta.

Muchid, A. (2015). Penyusunan Laporan Keuangan Berdasarkan Standar Akuntansi KeuanganEntitas Tanpa Akuntabilitas Publik (SAK-ETAP)(Kasus pada UD Mebel Novel'l di Banyuwangi).

Ria, A. (2018). Analisis Penerapan Aplikasi Keuangan Berbasis Android pada Laporan Keuangan UMKM Mekarsari Depok. Sosio E-Kons. https://doi.org/10.30998/sosioekons.v10i3.2900 
Suharsimi, A. (2013). Prosedur Penelitian: Suatu Pendekatan Praktik (Edisi Revisi). Jakarta: Rineka Cipta. https://doi.org/10.1017/CBO9781107415324.004

Umar, H. (2008). Metode penelitian untuk penulisan skripsi dan tesis. In PPM Manajemen. https://doi.org/10.1002/ajh.23895

Undang-Undang No. 20 Tahun 2008. (2008). Tentang: Usaha,Mikro,Kecil dan Menengah. Sekretariat Negara. Jakarta.

Warsita, Bambang. (2011). Landasan Teori Dan Teknologi Informasi Dalam Pengembangan Teknologi Pembelajaran. Teknodik, $X V$.

Widiastuti, I. (2015). Sistem Informasi Akuntansi Berbasis Komputer. Bhirawa. Vol. 2. No. 2 Edisi Desember 2015. https://doi.org/10.1111/dmcn.12016

Yahya, M. (2018). Era Industri 4.0: Tantangan Dan Peluang Perkembangan Pendidikan Kejuruan Indonesia.

https://kominfo.go.id/content/detail/13065/lamikro-aplikasi-laporan-keuangan-sederhana-untukusaha-mikro/0/artikel_gpr

https://www.kompasiana.com/nkurniadi/5af8fc58dd0fa85ee24ca9b3/lamikro-solusi-laporankeuangan-bagi-usaha-mikro 